\title{
A critical analysis of national policies, systems, and structures of patient empowerment in England and Greece
}

This article was published in the following Dove Press journal:

Patient Preference and Adherence

27 September 2017

Number of times this article has been viewed

\section{Markella Boudioni' \\ Susan McLaren ${ }^{2}$ \\ Graham Lister ${ }^{2}$}

'NIHR Imperial Biomedical Research Centre \& Patient Experience Research Centre, Imperial College London, ${ }^{2}$ Institute for Leadership and Service Improvement, Faculty of Health and Social Care, London South Bank University, London, UK
Correspondence: Markella Boudioni NIHR Imperial Biomedical Research Centre \& Patient Experience Research Centre, Imperial College London, St Mary's, Norfolk Place, Paddington, London W2 IPG, UK

Tel +447969284876

Email mboudioni@yahoo.co.uk
Background: Comparison of patient empowerment (PE) policies in European countries can provide evidence for improvement and reform across different health systems. It may also influence patient and public involvement, patient experience, preference, and adherence.

Objective: The objective of this study was to compare PE within national policies, systems, and structures in England and Greece for achieving integrated people-centered health services.

Methods: We performed a critical search and review of policy and legislation papers in English and Greek languages. This included 1) general health policy and systems papers, 2) PE, patient and/or public involvement or patients' rights policy and legislation (1990-2015), and 3) comparative or discussion papers for England and/or Greece.

Results: A total of 102 papers on PE policies, systems, and structures were identified initially; 80 papers were included, in which 46 were policy, legislative, and discussion papers about England, 21 were policy, legislation, and discussion papers about Greece, and 13 were comparative or discussion papers including both the countries. In England, National Health Service policies emphasized patient-centered services, involvement, and empowerment, with recent focus on patients' rights; while in Greece, they emphasized patients' rights and quality of services, with recent mentions on empowerment. The health ombudsman is a very important organization across countries; however, it may be more powerful in Greece, because of the nonexistence of local mediating bodies. Micro-structures at trusts/hospitals are comparable, but legislation gives more power to the local structures in Greece.

Conclusion: PE policies and systems have been developed and expressed differently in these countries. However, PE similarities, comparable dimensions and mechanisms, were identified. For both the countries, comparative research and these findings could be beneficial in building connections and relationships, contributing to wider European and international developments on PE, involvement, and patients' rights and further impact on patient preferences and adherence.

Keywords: patient empowerment, patient involvement, patients' rights, England, Greece, national health policies

\section{Introduction}

Patient empowerment $(\mathrm{PE})$ and its benefits ${ }^{1-6}$ have been recognized internationally and in Europe; empowerment and engagement are goals of a global strategy on the achievement of integrated, people-centered health services between 2016 and 2026. ${ }^{1}$ The Tallinn Charter recognized the importance of making health systems more responsive to patients' needs, preferences, and expectations, committing WHO 
Table I Patient empowerment concepts and definitions

\begin{tabular}{|c|c|}
\hline Concept & Definitions \\
\hline Patient empowerment (PE) & $\begin{array}{l}\text { Inclusive term, encompassing different levels, strategies, methods, and dimensions of involvement/participation, } \\
\text { including patient involvement and patients' rights across countries. }{ }^{18} \\
\text { Refers to all mechanisms enabling patients to gain control and make choices on their health and health interventions; } \\
\text { the act or process of conferring authority, ability, or control: } \\
\text { the process (or processes) of redressing the balance of power in health care between the individual } \\
\text { receiving care and the health care professional in a provider setting ... people obtaining the knowledge } \\
\text { and skills to make it possible for them to become active partners, with professionals, in making informed } \\
\text { decisions and choices about their own treatment and care; and of enabling communities to exert informed } \\
\text { influence on NHS service planning, development and delivery. }{ }^{19}\end{array}$ \\
\hline $\begin{array}{l}\text { Patient involvement }(\mathrm{PI}) \\
\text { or patient and public } \\
\text { involvement (PPI) }\end{array}$ & $\begin{array}{l}\text { Patient involvement }(\mathrm{PI}) \text { or patient and public involvement (PPI), a term commonly used in England, refers to active } \\
\text { participation of patients/carers and the public, as partners in their own care and treatment at various levels, ie, } \\
\text { health services planning, service delivery, quality monitoring, development. } .^{20}\end{array}$ \\
\hline Patients' rights & $\begin{array}{l}\text { Patients' rights, entitlements, and duties are what citizens can expect of health systems and providers of care, and } \\
\text { what is expected from them. }{ }^{21} \\
\text { Fundamental rights are those for information and complaining. Respect for the individual citizen's "voice" and } \\
\text { "choice" are the underpinning values of all rights. }{ }^{14}\end{array}$ \\
\hline
\end{tabular}

Member States in Europe to strengthening health systems. ${ }^{4}$ The European Community White Paper (2008/2013) recognized citizens' rights to be empowered in relation to health and health care, encompassing participation and influence on decision-making and competences needed for well-being. ${ }^{5}$ The value of patient engagement and empowerment has been discussed in international forums, bringing forward proposals for strengthening national approaches to patient engagement and the advocacy capacity of patients. ${ }^{7}$ Recently, WHO called for action on $\mathrm{PE},{ }^{8}$ recognizing that patient, family, and community engagement are assets for building capacity and quality of care. ${ }^{9}$

Diverse models of PE have been adopted internationally encompassing patients' rights legislation (the Netherlands and Greece), introducing ombudsperson services (Austria, Finland, Hungary, Norway, Greece, and England) and increasing patient participation in care decision-making in England. ${ }^{6,10-14} \mathrm{~A}$ developing consensus recognizes that $\mathrm{PE}$ is increasingly important to health governance, resulting in better system responsiveness to health consumer's views, preferences, and self-management of health. Both England and Greece, which have not been compared in relation to empowerment before, are engaged in professional, political, and public discussions about PE, sharing common European health policies, standards, and targets. ${ }^{1,4}$ Both the countries have recognized the benefits of making health systems and are more patient-centered and responsive by adopting PE strategies. ${ }^{15}$ It is acknowledged that they may have different health and welfare systems, PE national policies, systems, and development. This diversity can only be helpful in providing evidence for improving policies, organizational systems, management, professional practices, and patient experiences. Comparison of PE policies across two different health and welfare systems can illuminate similarities and differences, providing evidence for improvement and reform. ${ }^{16-18}$ It can also influence patient and public involvement in such policies and systems and impact on patient preferences and adherence.

The term "patient empowerment" is used as an inclusive term here, encompassing different levels, strategies, methods, and dimensions of involvement/participation, including patient and public involvement (PPI) and patients' rights across countries. It refers to all mechanisms enabling patients to gain control and make choices in their health and health interventions, ${ }^{19}$ the act or process of conferring authority, ability, or control. ${ }^{20}$ More choice, more information, and more personalized care may be elements leading to better health literacy, informed decision-making, and real empowerment of patients to improve their health, health services, and systems. There are many concepts and definitions relating to PE (Table 1); these have been discussed elsewhere and we do not revisit them in this paper. ${ }^{14,19-22}$ This paper aimed to compare PE within national policies, systems, and structures in England and Greece.

\section{Methods}

A wide-ranging critical policy and legislation review of papers in English and Greek language, using a structured approach was undertaken. Three categories of papers were reviewed: 1) general health policy and systems papers; 2) PE, PPI, or patients' rights policy and legislation (1990-2015); and 3) comparative or discussion papers, for England and/or 
Greece. Inclusion criteria were the terms "patient empowerment," "patient (and public) involvement," "patients' rights," "patient engagement," and "patient participation;" papers in English and Greek languages were included.

The review was conducted between April 2006 and September 2015. Combination of the following terms were searched: "patient empowerment," "patient (and public) involvement," "patients' rights," "patient engagement," "patient participation," "citizenship," "health policy" (implementation of health policy), and "organizational systems" (strategies, systems, structures, or mechanisms). The following databases, search engines, and websites were used:

- Department of Health in England, Ministry for Health and Social Solidarity (MHSS) in Greece, National Health Services (NHSs) in both countries and other governmental.

- King's Fund, Picker Institute Europe, World Health Organisation, European Community, Greek National

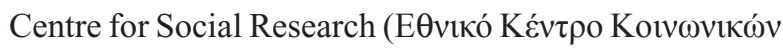

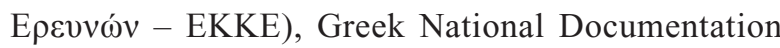

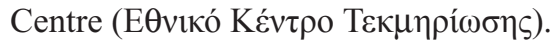

- Electronic databases: Medline, CINAHL, Greek medical databases, that is, Iatrotek.org, MedNet.gr.

All papers were screened by MB; summaries and any data considered dubious were discussed with the other co-authors. Only papers agreed by all the three authors were included. Exclusion criteria were that 1) they did not contribute to new knowledge in relation to the terms and aims and 2) they were not about Greece or England.

\section{Results}

Initially, 102 papers on PE policies, systems, and structures were identified. Of them, 80 papers were used and analyzed in the following sections: 46 were policy, legislative, and discussion papers about England; 21 were policy, legislation, and discussion papers about Greece; and 13 were comparative or discussion papers including both the countries. A short introduction about the general organization of the English and Greek NHSs is first presented, followed by the PE policies, systems, and structures in the two NHSs.

\section{The NHSs}

\section{England}

Established in 1948, the NHS centralized system, funded through national taxation, delivers services through public providers, devolving purchasing responsibilities to local bodies, that is, primary care trusts, clinical commissioning groups (CCGs). ${ }^{23,24}$ Health care spending is 9.1 of GDP (2013), medium compared to other countries and arguably equitable. ${ }^{11,25-27}$ Public health funding is high; private out-ofpocket funding is moderate. ${ }^{26}$ All citizens and residents are insured, but have limited provider choice or access to specialists. Only $10 \%$ have private health insurance, which gives higher quality care access and reduced waiting times. ${ }^{11,28}$ Initiatives focused on improving efficiency, responsiveness, and equity of the system, that is, foundation hospitals (2004) have greater management, financial responsibilities, and freedoms. Such measures aimed to reduce waiting lists, improve quality of provision, increase funding and staff numbers, encourage innovation, and extend patient choice. ${ }^{23}$ Despite these, it has been argued that patients are prevented from taking control of their health care and frontline professionals from revolutionizing services for patients' benefit. ${ }^{29}$ Although UK health policy has focused on controlling spending, the system faces serious financial strains, waiting lists, and explicit rationing for some types of care ${ }^{11}$ (Table 2).

\section{Greece}

The NHS inception in 1983 guaranteed free health care for all residents; introduced state responsibility for health care services provision, equal access, decentralization of planning, primary care development, exclusive employment of health care staff, and unification of main insurance funds. ${ }^{30}$ Health care spending is 9.8 of GDP (2013), medium compared to other countries. ${ }^{27}$ The system is characterized by a public-private mix for funding and delivery, high out-ofpocket payments, and little regulation of access to health care providers. ${ }^{11,26,31}$ Types of coverage available are the NHS, health insurance funds (occupation-based), and private health insurance. ${ }^{23}$ Most Greeks (95\%-97\%) have private insurance for hospital care. The health insurance system is employerbased; employers enroll their employees in a "social" payer system, the ministry controls employee contribution rates, insurance benefits and the doctors' social insurance funds. ${ }^{11}$ NHS services are provided through a public hospital network, delivering to inpatients and outpatients. Advances in accessing health care services include development of rural surgeries, primary health centers, and public and regional teaching hospitals. There are many challenges, that is, integrating primary care services, high level of pharmaceutical expenditure and modernizing NHS management. ${ }^{23}$ Public primary health care services are insufficiently developed, with the exception of some rural areas. Long waiting times for NHS care are partly due to provider shortages caused by low reimbursement rates. ${ }^{11,32,33}$ The system is characterized by over-centralization, fragmentation of coverage (with many insurance funds), regressive financing extensive 
Table 2 Main characteristics of the English and Greek National Health Services

\begin{tabular}{|c|c|c|}
\hline Characteristics & England & Greece \\
\hline \multirow[t]{3}{*}{ Funding } & Centralized, comprehensive, single-payer system, & Public and private mix for funding \\
\hline & funded by general tax revenues & Ministry regulation: single-payer system \\
\hline & Moderate private out-of-pocket payments & High out-of-pocket payments \\
\hline \multirow[t]{3}{*}{ Delivery } & $\begin{array}{l}\text { Mainly public delivery of services; devolved purchasing } \\
\text { responsibilities to local bodies, ie, PCTs, CCGs }\end{array}$ & Public and private delivery of services \\
\hline & Wide network of public hospitals & Wide network of public hospitals (inpatients and outpatients) \\
\hline & Strong public primary health care & Public primary health care insufficiently developed \\
\hline \multirow[t]{3}{*}{ Insurance } & National insurance: all citizens and residents & Employer-based health insurance system, "social insurance funds" \\
\hline & & $\begin{array}{l}\text { Coverage types: NHS, health insurance funds (occupation-based), } \\
\text { and private health insurance }\end{array}$ \\
\hline & Only $10 \%$ of people have private insurance & Most people (95\%-97\%) have private insurance \\
\hline Provider choice & Choice of public provider and access to specialists & Choice of public/private provider and health professionals \\
\hline Principles/initiatives & $\begin{array}{l}\text { Equal access to services by all, efficiency, } \\
\text { responsiveness }\end{array}$ & Equity, solidarity, equal access to services \\
\hline \multirow[t]{4}{*}{ Challenges } & Efficiency, quality, equality need strengthening & $\begin{array}{l}\text { Lack of primary care services; high pharmaceutical expenditure, } \\
\text { waiting lists }\end{array}$ \\
\hline & $\begin{array}{l}\text { Financial strains, waiting lists, explicit rationing } \\
\text { (selective) for some types of care, ie, kidney dialysis, }\end{array}$ & $\begin{array}{l}\text { Modernization of management; over-centralization/fragmented } \\
\text { service coverage }\end{array}$ \\
\hline & open heart surgery, and some other expensive & Extensive user' charges and informal payments \\
\hline & procedures and technologies & \\
\hline
\end{tabular}

Abbreviations: PCT, primary care trust; CCG, clinical commissioning group.

user charges and informal payments, inefficient resource allocation, perverse incentives for providers, and heavy reliance on unnecessarily expensive inputs ${ }^{26,32,35}$ (Table 2).

\section{PE policies \\ England}

NHS policies emphasized the need for patient/user input to service planning, development, delivery at all levels, monitoring, evaluation, audit, and their outcomes in the 1990s. ${ }^{35-39}$ The Patients Charter presented the first "aspirational" vision for hospital patients; the standards were not legal rights, but "major and specific standards" encompassing respect for privacy, dignity, religious and cultural beliefs, continuity of care, and quality of nursing. ${ }^{35}$ Other "rights" addressed waiting times, information (about cancellations), and timely responsiveness to complaints. ${ }^{35}$

The NHS Plan and "Shifting the Balance of Power" were the first patient-centered strategies in the 2000s encapsulating a vision where patients had more say about health care provision, marking the need for organizational and cultural change. ${ }^{40,41}$ Subsequently, significant policies, legislations, and frameworks aimed to empower patients and the public..$^{24,43-53}$ Importantly, patient and public involvement in planning, development, and making decisions affecting services operation became a duty enacted in the Health and Social Care Acts in 2001 and 2003. ${ }^{43,54}$ A subsequent Act (2006) placed a legal duty on health organizations to involve users/representatives through consultation, providing them with information about planning services, proposals for change, and decisions affecting service operation ${ }^{55}$ (Table 3).

The Next Stage Review (2008) placed quality at the heart of care, concentrating on patient-reported outcome measures, detailing elements of PE encompassing more information, choice, partnership working, and quality of care. ${ }^{56}$ Other guides and programs supported community, patient, and public engagement in health care..$^{57,58}$ The NHS Constitution brought together and explained patient's rights and public, patient, and staff responsibilities, thereby empowering all, for the first time in 2009. ${ }^{59}$ The Health Act 2009 placed a duty on all NHS providers to have regard to the Constitution, proposing measures to improve care quality, service performance, and public health. ${ }^{60}$ In 2013, new rights for both patients and staff were added, and patient involvement was updated in the Constitution ${ }^{61}$ (Table 4).

In the 2010s, the NHS White Paper Equity and Excellence envisioned "an NHS genuinely centered on patients and carers" encompassing an information revolution, greater choice and control through shared decision-making, increased patient control over records, and equity for everyone. ${ }^{62}$ The NHS 2010-2015 Plan together with more recent operating frameworks are even more empowering, emphasizing driving change through patient influence and integrating information around patients. ${ }^{63,64} \mathrm{~A}$ key tenet is "people must be given rights and entitlements, with greater control over their own health and care;" explicitly referring to rights, full choice of 
Table 3 A summary of patient empowerment policies and legislation in England and Greece (1990-2015)

\begin{tabular}{|c|c|c|}
\hline & Policy and legislative focus & Legislative/policy frameworks: documentary sources \\
\hline \multicolumn{3}{|c|}{ Empowerment policies and legislation 1990-1999 } \\
\hline \multirow[t]{3}{*}{ England } & $\begin{array}{l}\text { Need for patient input to the planning, development, delivery of } \\
\text { services }\end{array}$ & $\begin{array}{l}\text { The Patients Charter, 1991;35 Local Voices, 1992;36 A Service } \\
\text { with Ambition, 199637 }\end{array}$ \\
\hline & Patients charter: "major and specific standards" rather than "rights" & The Patients Charter, $|99|^{35}$ \\
\hline & $\begin{array}{l}\text { User involvement in monitoring, evaluation, services audit, and } \\
\text { outcomes }\end{array}$ & A Service with Ambition, $1996^{37}$ \\
\hline \multirow[t]{2}{*}{ Greece } & $\begin{array}{l}\text { Introduction of patients' rights, based on the European Charter of } \\
\text { Patients' Rights }\end{array}$ & Conservatives Reform and Law, $1992^{69}$ \\
\hline & $\begin{array}{l}\text { Emphasis on rights and hospital management; statutory bodies for } \\
\text { patients' rights protection established at national and hospital level }\end{array}$ & Health Care Reform and Law, $1997^{70}$ \\
\hline \multicolumn{3}{|c|}{ Empowerment policies and legislation 2000-2009 } \\
\hline \multirow[t]{8}{*}{ England } & First patient-centered policy reforms on shifting balance of power & NHS Plan, $2000 ;{ }^{40}$ Shifting the Balance of Power, $2002^{42}$ \\
\hline & $\begin{array}{l}\text { Legislation in health and social care enacted, placing a legal duty } \\
\text { involving users }\end{array}$ & Health and Social Care Acts 200I, 2003, 2006, 200943,54,55,60 \\
\hline & Giving service users a stronger voice at national/local level in & A Stronger Local Voice, 2006; ${ }^{49}$ Our Health, Our Care, our \\
\hline & $\begin{array}{l}\text { planning, development, and commissioning of services } \\
\text { Engagement of service users in achieving "high quality care for all" }\end{array}$ & $\begin{array}{l}\text { Say, 2006; } \text {; World Class Commissioning, 200/3i } \\
\text { Next Stage Review, } 2008^{56}\end{array}$ \\
\hline & Guidance on community engagement to improve health; a support & Community Engagement, 2008;57 PP Engagement Support \\
\hline & programme to support patient and public engagement in health care & Programme, 2009-2010 $0^{58}$ \\
\hline & Explanation of patients' rights and responsibilities in new NHS & NHS Constitution, 2009:59 Health Act, $2009^{60}$ \\
\hline & $\begin{array}{l}\text { Constitution; legislation places a duty on NHS providers to observe } \\
\text { new constitution }\end{array}$ & \\
\hline \multirow[t]{6}{*}{ Greece } & Citizens and their interests; reinforcement of the Office for Patient's & Health Care Reform and Law, $200 \mathrm{I}^{71}$ \\
\hline & Reception & \\
\hline & Quality, effectiveness, and efficiency: explicit NHS policy goals & \\
\hline & $\begin{array}{l}\text { Quality improvement in health services, living conditions in } \\
\text { public health context Collaboration of hospitals and non-profit } \\
\text { organizations reinforced }\end{array}$ & Health Care Reform and Law, $2005^{72}$ \\
\hline & Reinforcement of equity, service quality, protection of patient's rights & Ministry of Health and Social Solidarity's Mission, $2008^{73}$ \\
\hline & $\begin{array}{l}\text { Enhancing/promoting citizens' health by providing appropriate } \\
\text { information, empowering to remain healthy and best usage of health } \\
\text { and social care services }\end{array}$ & National Action Plan for Public Health, 2008-20I $2^{74}$ \\
\hline \multicolumn{3}{|c|}{ Empowerment policies and legislation 2010-2015 } \\
\hline \multirow[t]{4}{*}{ England } & $\begin{array}{l}\text { Driving change through patient influence and integrating information } \\
\text { around patients }\end{array}$ & NHS 20I0-20I5 Plan "From Good to Great" 63 \\
\hline & $\begin{array}{l}\text { Information revolution, greater choice, and control through norms } \\
\text { of shared decision making, increased patient control over records, } \\
\text { and equity for everyone }\end{array}$ & Equity and Excellence: Liberating the NHS, 201062 \\
\hline & $\begin{array}{l}\text { More patient choice enacted in law, with individual/public } \\
\text { participation duties }\end{array}$ & Health and Social Care Act, $2012^{65}$ \\
\hline & $\begin{array}{l}\text { Empowerment with access to electronic medical records. Involving } \\
\text { diverse communities and citizens directly in decisions about future } \\
\text { health and care }\end{array}$ & $\begin{array}{l}\text { NHS 5-year Forward View, 2014;67 NHS England Business } \\
\text { Plan, 2015-201666 }\end{array}$ \\
\hline \multirow[t]{2}{*}{ Greece } & Reinforcement of patient empowerment bodies & $\begin{array}{l}\text { Ministry of Health and Social Solidarity's Circulars and } \\
\text { Targets, } 2010^{91}\end{array}$ \\
\hline & $\begin{array}{l}\text { Empowerment mirroring positive health, emphasizing social and } \\
\text { individual capacities }\end{array}$ & National Action Plan for Human Rights, $2013^{75}$ \\
\hline
\end{tabular}

primary and secondary care services, more personal health responsibility, all increasing patient satisfaction. A significant proportion of provider income is linked to patient experience and satisfaction by linking payment to patient satisfaction, giving providers incentives to understand and improve. ${ }^{63}$ With the Health and Social Care Act (2012), NHS duties to offer more patient choice were enacted in law, including individual and public participation. ${ }^{65}$ The Health and Care System
(2013) gave local communities more say in care through health and well-being boards, envisioning that "everyone has greater control of their health and their wellbeing, supported to live longer, healthier lives by high quality health and care services that are compassionate, inclusive and constantlyimproving." ${ }^{66}$ The NHS 5-year Forward View emphasized a new relationship with patients and communities, that is, empowerment with access to electronic medical records. ${ }^{67}$ 
Table 4 A summary of patients' rights and entitlements in England and Greece

\begin{tabular}{lll}
\hline $\begin{array}{l}\text { Rights/ } \\
\text { entitlement }\end{array}$ & England $^{\mathrm{a}}$ & Greece $^{\mathrm{b}}$ \\
\hline $\begin{array}{l}\text { Access to } \\
\text { health care }\end{array}$ & $\begin{array}{l}\text { Access health services free of charge (limited exceptions by } \\
\text { Parliament) }\end{array}$ & $\begin{array}{l}\text { Access the most appropriate hospital services for the } \\
\text { disease/condition }\end{array}$ \\
& Never refused on unreasonable grounds & Collaboration between hospitals and non-profit health \\
& services in place & organizations ${ }^{c}$ \\
& No unlawful discrimination in NHS service provision & Equity in service delivery
\end{tabular}

Access certain services commissioned by NHS bodies within maximum waiting times, or NHS to take reasonable steps to offer range of suitable alternative providers

Quality of care/ environment

Treatment with a professional standard of care, by appropriately qualified and experienced staff, in an organization meeting required levels of safety/quality Expect NHS organizations to monitor, make efforts to improve, the quality of health care

Approval of treatment, drugs, programs

Use of drugs and treatments recommended by NICEf if doctor states clinically appropriate

Local decisions on funding of other drugs/treatments: following proper consideration of evidence

Local NHS must explain decision not to fund drug/treatment that patients/doctors think appropriate

Receive approved vaccinations under an NHS-provided national immunization program

Respect, consent, $\quad$ Be treated with dignity and respect confidentiality

Information, informed choice, involvement in own health care and NHS

Accept/refuse treatment, and not be given any examination/ treatment without valid consent

Be given information about proposed treatment in advance, including any significant risks/alternative treatments available, and risks without treatment

Privacy/confidentiality: NHS to keep confidential information safe/secure

Access to own health records

Choose GP practice and be accepted unless reasonable grounds to refuse exist

Express preference for choice of doctor within GP practice; practice to try to comply

Make choices about NHS care based on supporting information

Involvement in discussions/decisions about one's health care; be given information to enable one to do this

Involvement, directly or via representatives, in planning health services, development/consideration of proposals for changes in service provision and decisions affecting service operation

Rights of redress
Have complaints dealt with efficiently and properly investigated

Know outcome of complaint investigation

Refer complaint to Health Service Ombudsman, if dissatisfied with NHS process/outcome

Claim for judicial review if directly affected by an unlawful act/decision of an NHS body

Compensation if harmed by negligent treatment
Efficiency and quality

Give/refuse consent to diagnostic/therapeutic procedures ${ }^{\mathrm{e}}$

Receive care ${ }^{d}$ with due respect for dignity as human beings Give/refuse consent to diagnostic/therapeutic procedures ${ }^{\mathrm{e}}$ Procedures only performed with consent. Patients entirely free to decide whether or not to agree to collaborate for the purposes of research or training. Consent to such collaboration is their own right and they may withdraw at any time

Privacy/confidentiality must be guaranteed for content of documents concerning patient and the file in which medical notes are recorded. (Access to own health records is not explicitly stated)

Have religious and ideological beliefs respected Request information regarding health status. Guaranteed information provided is comprehensive and accurate Choice of public/private provider and health professionals Patients can obtain accurate picture of medical, social, and financial parameters of health status and participate in decision-making process likely to affect their life Patients/representatives informed in advance of risks likely to arise as a result of unusual or experimental diagnostic/ therapeutic procedures

Present complaints/objections

Be fully informed on effects and outcomes of complaints Refer complaint to Health Service Ombudsman, if dissatisfied with NHS process/outcome

Notes: ${ }^{2}$ NHS Constitution (2009) (incorporating 20I0, 20I2, and 2013 updates). ${ }^{84,86 ~ b}$ breek Parliament (207I/I992 Law), ${ }^{93}$ except otherwise specified. 'Greek Parliament $(3370 / 2005 \mathrm{Law}) .{ }^{96} \mathrm{C}$ Care covers practice of medicine, nursing, services of allied health care personnel, appropriate accommodation, treatment, administrative and technical services. elf suffering from total/partial mental incapacity, exercise of this right devolves upon person legally acting on their behalf. ${ }^{~} \mathrm{National}$ Institute for Clinical Excellence. Abbreviations: NHS, National Health Service; GP, general practitioner. 
Subsequently, the NHS England Business Plan (2015-2016) commits to innovative engagement with diverse communities and citizens, placing citizens at the center of design for new services and care models ${ }^{68}$ (Table 3).

\section{Greece}

Health care reforms in the 1990s and 2000s utilized legislation addressing patients' rights and service quality. ${ }^{68}$ The Conservatives' Reform in 1992 introduced patients' rights based on the European Charter; the most significant being rights of information, complaint, appropriate services, respect, and choice/refusal of treatment ${ }^{69}$ (Table 4). The Health care Reform in 1997 also emphasized patients' rights and effective hospital management of utilizing user's views in decisionmaking, through establishment of statutory bodies for rights' protection at national and hospital level ${ }^{70}$ (Table 3 ).

The following Health care Reform (2001) focused on Greek citizens and their interests, reinforcing the statutory bodies established in 1997 (below). ${ }^{71}$ This reform aimed to a patient-centered NHS, incorporating basic measures of universal coverage and equity in service delivery, efficiency, and quality. ${ }^{34}$ Reforms were to be achieved through the establishment of National Health Institute's Regional Health Authorities and improved public hospitals with appointment of professional managers. The later Health care Reform (2005) addressed living conditions in the wider public health context; health priorities emphasizing equal access and need satisfaction. Official endorsement of collaboration of hospitals and nongovernmental health organizations was given. ${ }^{72}$ Patients' rights continued to be reinforced in 2008 with the MHSS' mission emphasizing equality, quality of services, and protection of individual and social rights. ${ }^{73}$

Despite subsequent lack of reforms, recent National Action Plans were patient empowering. The National Action Plan for Public Health (2008-2012) explicitly mentions "information" and "empowerment of citizens." The National Action Plan for Human Rights (2013) explains rights to health and refers to "empowerment" as mirroring positive health, emphasizing social and individual capacities. ${ }^{75}$

\section{PE systems and structures}

\section{England}

National organizations, systems, and initiatives

National organizations' monitoring, regulating, and inspecting health care services, that is, the Care Quality Commission (2009), replacing the Health Care (2004) and the Mental Health Act Commissions (1983), have been active since the 1980s. ${ }^{76,77}$ National organizations empowering, protecting, and strengthening patients and public have also been active; of these, the Health Service Ombudsman, established in 1973, considers complaints that the NHS has not acted properly, fairly, or provided a poor service. ${ }^{78}$ This statutorily independent investigator has powers to summon witnesses and access records, breaches of which can be treated as akin to contempt of court. ${ }^{14,78}$ Other bodies now abolished, that is, the Commission for Patient and Public Involvement in Health (CPPIH) (2004-2007) and the National Resource Centre for Patient and Public Involvement (2006-2009), aimed to promote PPI value, and the latter to create a single point for information and advice (Table 5). ${ }^{79,80}$

Changes implemented at the macro level included several choice initiatives, that is, the "Choose and Book" service, enabling patients requiring elective care to see information about hospitals and book first appointments through general practice surgeries or a booking service. ${ }^{81}$ Patient feedback was facilitated via annual hospital patient surveys, undertaken by NHS acute hospital trusts between 1997 and 2013. Over time, surveys expanded to include topics of public and/or political interest, that is, waiting times, single sex wards, and cleanliness. Wider annual national surveys were undertaken for inpatients (2002-2007) and outpatients (2003, 2004/2005) together with surveys on specific services or conditions. ${ }^{82}$ In 2013, the Friends and Family Test was introduced, asking service users if they would introduce a service to friends and families. ${ }^{83}$ A new NHS Citizen Program was co-designed (2013), enabling NHS England to directly engage citizens in a publicly accountable and transparent forum, providing a framework for citizens to engage commissioners and providers of services, offering views, insights, and solutions, holding them to account. Since the program began, NHS England has facilitated workshops and regional events, with face to face and digital participation. ${ }^{83}$

\section{Local and trust/hospital systems and structures}

Systems empowering patients and the public at the micro local/hospital level are also prevalent (Table 5). Community Health Councils (1974), the first formal structures to represent public interests locally, were abolished in $2003 .^{84}$ Their role was taken over by other services:

- Overview and Scrutiny Committees (2000), a statutory service, established to look at the local NHS work with local authority councillors having the powers to review and scrutinize the planning, provision, and operation of health services and to make improvement in recommendations. ${ }^{85}$ 
Table 5 A summary of NHS patient empowerment systems and mechanisms in England and Greece (1973-2015)

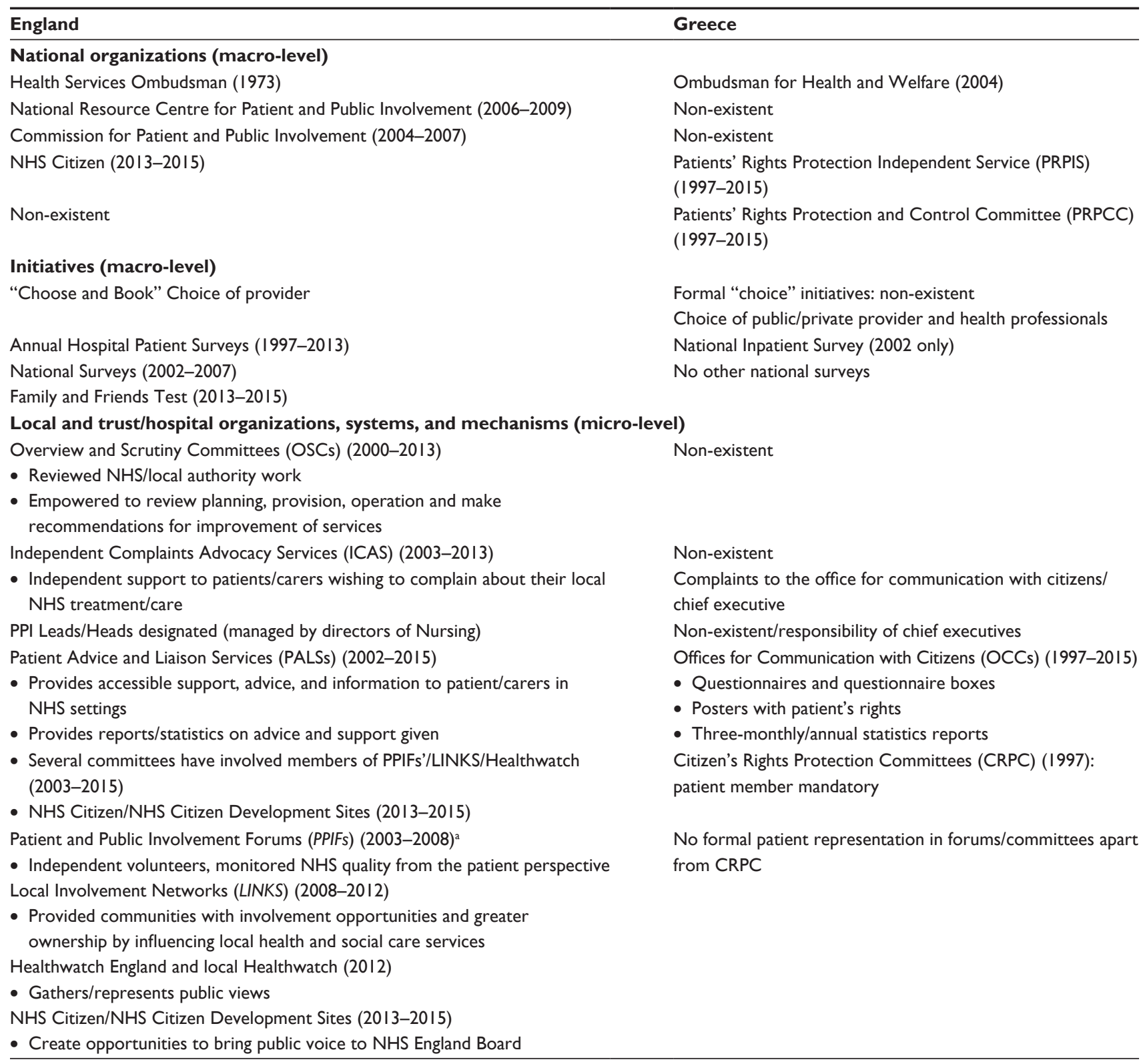

Note: aPPIFs were replaced by LINKs (2008) and more recently with Healthwatch England and local Healthwatch (2012, 2013).

- Independent Complaints Advocacy Service (ICAS) (2003), another statutory service, launched aiming to provide independent support to patients/carers wishing to complain about their NHS treatment and care locally. ${ }^{45}$

- Patient Advice and Liaison Services (PALS) (2002) established aiming to provide accessible support, advice, and information to patient/carers in NHS settings. ${ }^{40}$

- Patient and Public Involvement Forums (PPIFs) (2003), independent bodies made up of volunteers, set up to monitor the NHS quality from the patient perspective. PPIFs were supported by the CPPIH. ${ }^{40}$
Recently, NHS Citizen Development Sites (2014) provide opportunities for people in local areas to make links with the NHS Citizen Program, bringing public voice to the board of NHS England. ${ }^{86}$

\section{Greece}

National organizations, systems, and initiatives

The Health and Welfare Inspectorate, established to provide good quality services to citizens, has been active since $2001 .^{87}$ It has a repressive and preventative role by conducting checks and audits and suggesting imposition of 
punishments or staff disciplinary control, simultaneously checking relevant procedures and making propositions. Although under the jurisdiction of the MHSS, it has full inspection independence collaborating with the Patients' Rights Protection and Control Committee (PRPCC) (below). ${ }^{88}$ Other national bodies promote, protect, and strengthen patients' rights. The Greek ombudsman for Health and Welfare, established in $2004^{89}$ as part of the Greek Ombudsman duties, ${ }^{70}$ is the most prevalent. It suggests measures to the ministry for restoration and protection of patients' rights; elimination of bad management, improvements in health and social welfare services, and relationships with citizens ${ }^{89}$ (Table 5).

National statutory bodies to protect patients' rights were introduced in 1997..$^{70}$ The Patients' Rights Protection Independent Service (PRPIS) was established to monitor patients' rights protection, investigate formal written complaints, and report progress to the Ministry's Secretary General. It requires annual hospital reports on their Office for Communication with Citizen (OCC) activities encompassing annual complaints, their resolution, time spent on complaint investigations, and decisions taken. PRPIS has the right to suggest solutions, request further investigations, and make recommendations. Although part of the MHSS, it has independent status. ${ }^{70}$ PRPIS proposed establishment of reception desks (welcome points) in all public hospitals, staffed by OCCs, to make available information leaflets on patients' rights and PRPIS functions. ${ }^{71}$

The PRPCC was also established (1997) to ensure hospital compliance with patients' rights regulation and conduct indepth, national investigations of complaints. ${ }^{70}$ It comprises a State Legal Council representative and representatives of 13 professional Greek institutions from a spectrum of professions. Once a decision regarding a patient complaint is made, the Ministry's Secretary General is notified and ensures that appropriate actions are taken by hospital management. However, it has been under-functioning since 2005 .

In 1999, two new bodies answering directly to the ministry were launched within the PRPIS: an "Office for the Protection of Individuals with Psychological Disorders" to protect the rights of these individuals and a "Special Committee for the Rights of Individuals with Psychological Disorders' to ensure compliance with the Office." ${ }^{\prime 99}$ A national inpatient survey (2002) was also introduced following the 2001 reforms, aiming to evaluate public hospitals by measuring users' satisfaction $;{ }^{90}$ plans for ongoing annual surveys, however, were not materialized.
Hospital systems and structures

Statutory bodies were also established within all hospitals in $1997 . .^{70}$ OCCs acted as information points for patients/ service users, registering complaints, operating under direct supervision of hospital chairmen/chief executives. ${ }^{71}$ They became "Offices of Patients' Reception," and their role changed slightly to welcoming and directing patients, accompanying them to the appropriate hospital services in 2001; thus, reception desks (welcome points) were created in all public hospitals. ${ }^{71}$ In 2010, MHSS' circulars and targets included commencement of quality monitoring processes and reinforcement of the OCCs. ${ }^{92}$ A circular reminded all hospitals that "an Office of Patients' Reception - Office of Communication with Citizen, staffed suitably, should exist in visible location near the entrance in every infirmary." ${ }^{.93}$ Their aim was the reception, information, update, direction, and support of all patients and those accompanying them, about complaint procedures and information on hospital rules. Thus, a double more inclusive role with extensive responsibilities was allocated to the offices. The same year they were renamed to "Offices for Citizen's Support," responsible for the patient welcoming, information, movement control, administrative support, management and dispatch of concerns, complaints, and overall protection of patients' rights. ${ }^{94}$

Citizens Rights' Three-member Protection Committees (CRPCs), established in 1997, investigated complaints and protected and promoted patients' rights in collaboration with the OCCs for which it had a monitoring function. Its membership should include a user representative; the Board of Directors should ensure that all hospital patients were aware of their rights. CRPCs membership comprised a hospital manager/chair, the directors of medical and nursing services (user representative details not stated). In addition, other structures were introduced in 2010 reinforcing patient organizations and volunteering, and also evaluation, monitoring, and reporting, that is, Consultation Councils for Transparency and Monitoring in Health and Social Welfare, the "Registry for Volunteering in Health and Social Care." ${ }^{\prime 4}$

\section{Cross-national analysis and discussion}

This is the first paper to compare national policies, systems, and structures for PE in England and Greece. Notwithstanding its limitations, that is, based on a critical policy and legislation review in English and Greek language, and not taking into account patients, public, and other stakeholders' 
perspectives and preferences, it has highlighted the important differences and similarities.

\section{The NHSs and PE policies}

English and Greek NHSs, having been developed differently, have diverse characteristics and face substantive challenges (Table 2) with significant implications for PE. Both NHSs, committed to equity in service access, face serious financial strain, patients experience disempowering effects of waiting lists (both), rationing (England), extensive user charges, and informal payments (Greece). Despite these challenges, both the countries have recognized the benefits of making health systems more patient-centered and responsive by adopting PE strategies and have invested in infrastructures to support policy implementation despite financial constraints. ${ }^{15}$

In England, policies and legislation have focused on patient-centered quality services, explicit PPI, engagement, empowerment, and more recently on patients' rights. In Greece, the policy and legislative focus has been on patients' rights, statutory bodies to protect rights and quality of services, with only a very recent focus on "empowerment" (Table 3). Patients' rights encompass human, social, and individual rights, addressing quality and accessibility of health care as well as basic consumer rights, balancing the partnership between providers and individual receivers of care. ${ }^{95}$ Common dimensions of PPI and patients' rights are information and complaining. Patients' "voice" and "choice" are other common dimensions, requisite for PPI and underpinning values for all rights..$^{14,21,96}$ Although these may be comparable elements, their focus, emphasis, and implementation may differ, that is, information, complaining, "choice," and "voice" may have different meanings and take different forms in the two countries. The timing and the development of patients' rights also differ greatly; since the introduction of patients' rights in 1992, there have not been great developments in Greek legislation, perhaps with the exception of the most recent introduction of the term "empowerment," while patients' rights have been developed and expanded greatly since the NHS Constitution in 2009 in England (Table 4). However, there may be recent convergence of policies; patients' rights were introduced as important PE mechanisms in England in 2009 and have been strengthened since then; and PE has been emphasized in Greek policies more recently.

Challenges existed in implementing PE policies and reforms in both the countries slowing down the pace of change. In England, reports noted barriers to patients taking control of their health and health professionals revolutionizing services. ${ }^{11,29}$ In Greece, a need exists to modernize organizational management, tackle sources of over centralization/fragmentation of services and resolve factors which led to a hiatus in reforms post 2008..$^{31,25,29}$ The recent economic crisis has severely affected the implementation of policies in health and health care in Greece, that is, health care budgets have been slashed; in England, recent health budget cuts are also evident. ${ }^{97,98}$ However, in both the countries, recent developments suggest positive attempts to move policy implementation forward, that is, the National Action Plan for Human Rights ${ }^{75}$ in Greece explains and emphasizes on rights to health, and the recent NHS England Business Plan influences empowerment and engagement of citizens in decisions about future service design. ${ }^{66}$

These developments may not be suprising, as policy makers are expected to implement human-centered approaches, safeguarding dignity and rights to face financial cuts and crisis. ${ }^{99,100}$

\section{PE systems and structures}

Diverse systems and structures have been implemented in both the countries to support PE, patient and public involvement, and patients' rights (Tables 4 and 5). At a macro-level, the independent health ombudsman role is of vital importance in both the countries. However, in Greece because of the nonexistence of local independent organizations or mediating bodies, its role assumes greater importance. National organizations/committees have been set up to protect rights in both the countries, that is, PRPIS and PRPCC in Greece and the NHS citizens in England.

At trust/hospital micro-level, committee structures with patient representation have also been implemented in both the countries to support PE. Although PALSs and OCCs' functions are comparable, PALS have been stable over the years, but legislation in Greece continues to devolve power to OCCs, although one could argue that their name change and slightly diminished role may have created confusion among staff and patients, limiting their functions (Table 5). Furthermore, policy recommendations and implementation guidance for local organizations have been weak in England and required improvement; in contrast, in Greece some guidance and monitoring systems for OCCs is in place. Other PE mechanisms at the local level, that is, the ICAS in England and the Citizen's Rights Protection Committees (CRPCs) in Greece are acknowledged as areas of difference between the two systems. Important systemic and cultural connotations for PE, essential in dealing with the deficiencies of each system and alternative coping mechanisms are highlighted 
elsewhere, that is, the role of the voluntary sector in both the countries and the family's role in Greece. ${ }^{101,102}$

At both macro- and micro-level, monitoring, audit and evaluation investigating $\mathrm{PE}$ issues from both patient and professional perspectives is helpful in providing evidence for improving policies, organizational systems, management, professional practices, and the patient experience. In both the countries, patient surveys (Table 4) have been utilized for these purposes, most frequently and consistently in England; in Greece, greater use of survey research or use of alternative feedback forums (currently lacking) would give greater weight to policy development and reform.

\section{Conclusion}

The NHSs policies and legislations linked to PE were very different in England and Greece; in turn, PE systems, structures, and mechanisms reflect these influences in England and Greece. Different language and terminology have been used, that is, "patient (and public) involvement" and "engagement" in England, "patients' rights" and "responsibilities" in Greece. However, PE similarities, comparable dimensions, and mechanisms were also identified.

Future studies could draw on these findings and explore how the implementation of PE policies and legislation may influence PE within organizations, that is, hospitals, in both individual and organizational levels. Further research in implementation of national systems, structures, and mechanisms, investigating PE from both patient and professional perspectives could provide evidence for improving policies, organizational systems, management, professional practices, and patient experience, preference, and adherence. For both the countries, comparative research could be beneficial in building connections and relationships, help to bridge the gap between research and policy implementation and contribute to wider European and international developments on $\mathrm{PE}$, involvement and patients' rights. Furthermore, the importance of patient and public involvement in such developments and how these factors impact on patient preference and adherence should be explored and highlighted.

\section{Acknowledgments}

We would like to thank all those who helped us with the literature review. This work was part of a $\mathrm{PhD}$ study, funded privately and supported by London South Bank University.

\section{Disclosure}

The authors report no conflicts of interest in this work.

\section{References}

1. World Health Organisation. Placing People and Communities at the Centre of Health Services. WHO Global Strategy on Integrated People-Centred Health Services 2016-2026. Geneva: WHO; 2015.

2. World Health Organisation. Ottawa Charter for Health Promotion. The Move towards a New Public Health. Ottawa 17-21 November 1986. Ottawa: WHO; 1986.

3. World Health Organisation. The Jakarta Declaration on Leading Health Promotion into the 21st Century. Fourth International Conference on Health Promotion. Jakarta: WHO; 1997. Available from: http://www. who.int/healthpromotion/conferences/previous/jakarta/declaration/en/. Accessed August 8, 2013.

4. World Health Organisation. The Tallinn Charter: Health Systems for Health and Wealth. Copenhagen: WHO Regional Office for Europe; 2008. Available from: www.euro.who.int/document/e91438.pdf. Accessed August 8, 2013.

5. Commission of the European Communities. White Paper - Together for Health: a Strategic Approach for the EU 2008-2013. COM (2007) 630 final. Brussels: COM; 2007.

6. All Party Parliamentary Groups on Global Health. Patient Empowerment: for Better Quality, More Sustainable Health Services Globally. A Report by the All Party Parliamentary Groups on Global Health; HIV/AIDS; Population, Development and Reproduction Health; Global Tuberculosis; and Patient and Public Involvement in Health and Social Care. London: All Party Parliamentary Groups on Global Health; 2014.

7. International Alliance of Patients Organisations. 4th Global Patients Congress: Exploring the Value of Patient Engagement in Strengthening Healthcare Globally. London: IAPO; 2010.

8. World Health Organisation. Patients Have a Voice Too! Geneva: WHO; 2013. Available from: http://www.who,int/gpsc/5may/5may2013_ patient-participation/en/. Accessed August 15, 2014.

9. World Health Organisation. Building Capability beyond the Health Sector to Deliver Universal Health Coverage. Background report to inform the Global Strategy for Human Resources for Health. Geneva: WHO; 2014.

10. Lister G. Public engagement in health policy: international lessons. J Man Mark. 2007;1(2):1-12.

11. Tanner MD. The grass is not always greener: a look at National Healthcare Systems around the world. Cato Inst Policy Anal. 2008;613: $1-48$.

12. World Health Organisation. Ninth Futures Forum on Health Systems Governance and Public Participation. Copenhagen: WHO; 2006. Available from: www.euro.who.int/document/e89766.pdf. Accessed September 17, 2012.

13. World Health Organisation. The European Health Report 2009: Health and Health Systems. Copenhagen: WHO Regional Office for Europe; 2009.

14. Mackenney S, Fallberg L. Protecting Patients'Rights? A Comparative Study of the Ombudsman in Healthcare. Oxon: Radcliffe Medical Press Ltd; 2004.

15. Busse R, Allin S, Maier C. Responding to citizens' expectations? The role of health services in responsiveness and satisfaction. In: Figueras J, McKee M, Lessof S, Duran A, Menabde N, editors. Health Systems, Health and Wealth: Assessing the Case for Investing in Health Systems. Copenhagen: WHO Regional Office for Europe; 2008:83-92. Available from: http://www.euro.who.int/document/hsm.3_hsco8_eBD3.pdf. Accessed September 17, 2012.

16. Ovretveit J. Comparative and Cross-cultural Health Research: a Practical Guide. Oxon: Radcliffe Medical Press Ltd; 1998.

17. Commission of the European Communities. Communication from the Commission to the Council, the European Parliament, the Economic and Social Committee and the Committee of the Regions on the Health Strategy of the European Community. COM (2000) 285 final, 2000/0119 (COD). Brussels: COM; 2000. 
18. Commission of the European Communities. Council conclusions on common values and principles in European Union Health Systems (2006/C146/01). Official Journal of the European Union. 2006;C146/1.

19. O'Cathain A, Goode J, Luff D, Strangleman T, Hanlon G, Greatbatch D. Does NHS Direct empower patients? Soc Sci Med. 2005;61:1761-1771.

20. Farrel C, Gilbert H. Healthcare Partnerships: Debates and Strategies for Increasing Patient Involvement in Healthcare and Health Services. London: King's Fund; 1996.

21. Kelson M. User Involvement: A Guide to Developing Effective User Involvement Strategies in the NHS. London: College of Health; 1997.

22. Bryne D. Enabling Good Health for All: A Reflection Process for a New EU Health Strategy. Luxembourg: European Commission; 2004.

23. World Health Organisation. Snapshot of health systems. GroseeTebbe S, Figueras J, editors. Copenhagen: WHO, European Observatory on Health Systems and Policies; 2005.

24. NHS England. Patient-Led Decision-Making, Empowerment and Innovation. NHS Values Summit, 4th November 2013. Leeds: NHS England; 2013. Available from: https://www.england.nhs.uk/wpcontent/uploads/2013/11/dcsn-mkng-ptnt-com-empow.pdf. Accessed August 15, 2015.

25. Sapir A. Globalisation and the Reform of European Social Models. Bruegel Policy Contribution. Background document for the presentation of ECOFIN Informal Meeting, Manchester, September 2005. Bruegel: Bruegel Policy; 2005. Available from: www.bruegel.org. Accessed December 12, 2012.

26. Wendt C. Mapping European healthcare systems: a comparative analysis of financing, service provision and access to healthcare. J Eur Soc Pol. 2009; 19:432.

27. World Bank. World Health Organisation Global Health Expenditure; 2013. Available from: http://data.worldbank.org/indicator/SH.XPD. TOTL.ZS/. Accessed December 12, 2012.

28. Healthcare Economist. Healthcare Around the World: Great Britain. Healthcare Economist; 2008. Available from: http://healthcare-economist. com/2008/04/23/health-care-around-the-world-great-britain/. Accessed December 12, 2012.

29. CIVITAS, Gubb J. Why the NHS is the sick man of Europe. CIVITAS Rev. 2008;5(1):1-11.

30. Greek Parliament. 1397/1983 Law. Available from: http://www. et.gr/index.php?option=com_wrapper\&view=wrapper\&Itemid $=10$ 8\&lang=en. Accessed January 25, 2013.

31. Economou C. Greece: health system review. Health Systems Trans. 2010;12(7):1-180.

32. Michailidou S. User Involvement in Greek Public Hospitals: Opportunities and Barriers [unpublished thesis]. Birmingham: The University of Birmingham; 2005.

33. Healthcare Economist. Healthcare around the world: Greece. Healthcare Economist; 2008. Available from: http://healthcare-economist. com/2008/04/22/health-care-around-the-world-greece/. Accessed January 25, 2013.

34. Davaki K, Mossialos E. Plus ca Change: Health Sector Reforms in Greece. J Health Pol Pol Law. 2005;30(1-2):143-168.

35. Department of Health. The Patient's Charter: Raising the Standard. London: DoH; 1991.

36. NHS Management Executive. Local Voices: The Views of Local People in Purchasing for Health. Leeds: NHSME; 1992.

37. Department of Health. The NHS: A Service with Ambitions. London: National Health Service Office; 1996.

38. NHS Executive. Patient Partnership: Building a Collaborative Strategy. Leeds: NHSE; 1996.

39. NHS Executive. Promoting Clinical Effectiveness: A Framework for Action in and through the NHS. Leeds: NHSE; 1996.

40. Her Majesty's Stationary Office. The NHS Plan: A Plan for Investment, a Plan for Reform. London: HMSO; 2000.

41. Department of Health. Shifting the Balance of Power within the NHSSecuring Delivery. London: DoH; 2001.

42. Department of Health. Shifting the Balance of Power: The Next Steps. London: DoH; 2002.
43. Department of Health. Strengthening Accountability: Involving Patients and the Public, Practice Guidance, Section 11 of the Health and Social Care Act 2001. London: DoH; 2003.

44. Department of Health. Building on the Best: Choice, Responsiveness and Equity in the NHS. Leeds: DoH; 2003.

45. Department of Health. Independent Complaints Advocacy Service; 2003. Available from: http://webarchive.nationalarchives.gov.uk/+/www.dh.gov. uk/en/Managingyourorganisation/Legalandcontractual/Complaintspolicy/ NHScomplaintsprocedure/DH_4087428. Accessed January 25, 2013.

46. Department of Health. Creating a Patient-Led NHS: Delivering the NHS Improvement Plan. London: DoH; 2004.

47. Department of Health. Better Information, Better Choices, Better Health: Putting Information at the Centre of Health. Leeds: DoH; 2004.

48. Department of Health. 'Now I Feel Tall' - What a Patient-led NHS Feels Like. London: DoH; 2005.

49. Department of Health. A Stronger Local Voice. London: DoH; 2006.

50. Department of Health. Our Health, Our Care, Our Say: A New Direction for Community Services. London: DoH; 2006. Available from: http://www.dh.gov.uk/en/Publicationsandstatistics/ Publications/PublicationsPolicyAndGuidance/DH_4127602. Accessed January 25, 2013.

51. Department of Health. World Class Commissioning. London: DoH; 2007.

52. Department of Health. The NHS in England: The Operating Framework for 2008/09. London: DoH; 2007.

53. Department of Health. The NHS in England: The Operating Framework for 2009/10. London: DoH; 2008.

54. Office of Public Sector Information. Health and Social Care (Community Health and Standards) Act 2003. London: OPSI; 2003.

55. Office of Public Sector Information. National Health Service Act 2006. London: OPSI; 2006. Available from: http://www.legislation.gov.uk/ ukpga/2006/41/contents. Accessed January 25, 2013.

56. Department of Health. High Quality Care for All: NHS Next Stage Review Final Report. London: DoH; 2008.

57. National Institute for Health and Clinical Excellence. Community Engagement to Improve Health, NICE Public Health Guidance 9. London: NICE; 2008.

58. Department of Health. Helping the NHS Put Patients at the Heart of Care: the Patient and the Public Engagement Support Programme 2009-10. London: DoH, Patient and Public Engagement; 2009.

59. Department of Health. The NHS Constitution for England. London: DoH; 2009.

60. Office of Public Sector Information. Health Act 2009. London: OPSI; 2009. Available from: http:/www.opsi.gov.uk/acts/acts2009/ ukpga_20090021_en_1. Accessed January 25, 2013.

61. Department of Health. The Handbook to the NHS Constitution. London: NHS Constitution Team, DoH; 2013. Available from: https://www. england.nhs.uk/2013/03/nhs-constitution/. Accessed August 12, 2015.

62. Department of Health. Equity and Excellence: Liberating the NHS. London: DoH; 2010.

63. The Stationary Office. NHS 2010-2015: From Good to Great. Preventative, People-Centred, Productive. London: TSO; 2009.

64. Department of Health. The NHS in England: The Operating Framework for the NHS in England 2010/11. London: DoH; 2010.

65. Office of Public Sector Information. Health Act 2012. London: OPSI; 2012.

66. NHS England. The NHS England Business Plan (2015-16). Leeds: NHS England; 2015.

67. NHS England. The NHS 5-Year Forward Plan. London: NHS England; 2014. Available from: http://www.england.nhs.uk/wp-content/ uploads/2014/10/5yfv-web.pdf. Accessed August 25, 2015.

68. Abel-Smith B, Calltorp J, Dixon M, et al. Report on the Greek Health Services. Athens, Greece: Ministry of Health and Welfare; 1994.

69. Greek Parliament. 2071/1992 Law. Available from: http://www.et.gr/ index.php?option=com_wrapper\&view=wrapper\&Itemid=108\&lang=en. Accessed January 25, 2015.

70. Greek Parliament. 2519/1997 Law. Available from: http://www. et.gr/index.php?option=com_wrapper\&view=wrapper $\&$ Itemid $=10$ 8\&lang=en. Accessed January 25, 2015. 
71. Greek Parliament. 2889/2001 Law. Available from: http://www. et.gr/index.php?option=com_wrapper $\&$ view $=$ wrapper $\&$ Itemid $=10$ 8\&lang=en. Accessed January 25, 2015.

72. Greek Parliament. 3370/\$81A/11.07.05 Law. Available from: http:// www.et.gr/index.php?option=com_wrapper\&view=wrapper\&Itemid= 108\&lang=en. Accessed January 25, 2015.

73. Ministry of Health and Social Welfare. The Ministry's Mission. Athens: MHSS; 2008. Available from: http://www.yyka.gov.gr/ministry. Accessed January 25, 2015.

74. Ministry of Health and Social Welfare. National Action Plan for

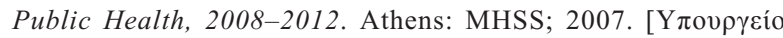

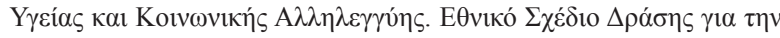

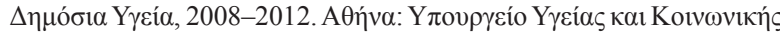
A $\lambda \lambda \eta \lambda \varepsilon \gamma \gamma$ ๆ́; 2007.] Available from: http://www.ygeianet.gov.gr/files. aspx?code=nationalactionplans. Accessed January 25, 2015.

75. Ministry of Justice. National Action Plan for Human Rights. Athens:

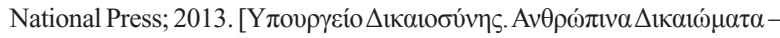

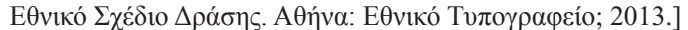

76. Healthcare Commission. Help to Improve your Health Services (Consultation Document). London: Healthcare Commission; 2004.

77. Care Quality Commission, 2009. Care Quality Commission. Available from: http://www.cqc.org.uk/about-us. Accessed August 12, 2015.

78. The Stationery Office. The Parliamentary Ombudsman: Withstanding the Test of Time. 4th Report, Session 2006-2007. London: TSO; 2007

79. Department of Health. Involvement is power: Rosie Winterton announces details of national resource centre for patient and public involvement. London: DoH; 2006. Available from: http://webarchive.nationalarchives gov.uk/+/http://www.dh.gov.uk/en/Publicationsandstatistics/ Pressreleases/DH_4135353. Accessed January 25, 2012.

80. National Centre for Involvement. Patient Involvement, Empowerment and Information. Keynote presentation from Executive Director, The New National Centre for Involvement. Patient Involvement, Empowerment and Information 2006, 4th Annual Conference. London: NCI; 2006.

81. Department of Health. Choose \& Book: Patient's Choice of Hospital and Booked Appointment. London: DoH; 2004. Available from: http:// webarchive.nationalarchives.gov.uk/20121107181829/http:/www. chooseandbook.nhs.uk/documents/implementation/choose_and_book_ policy_framework.pdf. Accessed January 25, 2012.

82. Goodrich J, Cornwell J. Seeing the Person in the Patient: the Point of Care Review Paper. London: The King's Fund; 2009.

83. NHS England. Annual Review 2013-2014 - A Year of Putting Patients First. Redditch: NHS England; 2014.

84. Socialist Health Association. Community Health Councils - The Old rules. London: Socialist Health Association; 1998. Available from: http://www.sochealth.co.uk/national-health-service/health-law/ community-health-councils-the-old-rules/. Accessed January 25, 2012.

85. The Stationary Office. The Local Authority (Overview and Scrutiny Committees Health Scrutiny Functions) Regulations 2002. London: TSO; 2002. Available from: http://www.opsi.gov.uk/si/ si2002/20023048.htm. Accessed January 25, 2012.

86. NHS Citizen. What Is NHS Citizen \& What Are the Development Sites. London: NHS Citizen; 2015. Available from: https://nhscitizen.public-i. tv/core/portal/home. Accessed August 12, 2015.

87. Greek Parliament. 2920/Ф131 A/2001 Law. Health and Welfare Inspectorate and Other Regulations. Available from: http://www.et.gr/index. php?option=com_wrapper \&view=wrapper \&Itemid=108\&lang=en . Accessed January 25, 2012.

Patient Preference and Adherence

\section{Publish your work in this journal}

Patient Preference and Adherence is an international, peer-reviewed, open access journal that focuses on the growing importance of patient preference and adherence throughout the therapeutic continuum. Patient satisfaction, acceptability, quality of life, compliance, persistence and their role in developing new therapeutic modalities and compounds to optimize
88. Health and Welfare Inspectorate. Annual Report. Athens: Health

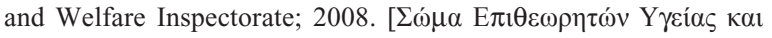

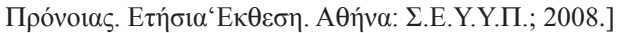

89. Greek Parliament. 3293/Ф231A/26.11.04 Law. Greek Ombudsman for Health and Welfare. Available from: http://www.et.gr/index. php?option=com_wrapper \&view=wrapper $\&$ Itemid=108\&lang=en. Accessed January 25, 2012.

90. Greek Parliament. 2716/1999 Law. Available from: http:/www. et.gr/index.php?option=com_wrapper $\&$ view $=$ wrapper $\&$ Itemid $=108$ \&lang=en. Accessed January 25, 2012.

91. Niakas D. Measurement of Patient Satisfaction in ESY Hospitals. In: Niakas D, editor. Issues about Health Services Management. Athens: Medi-

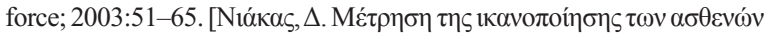

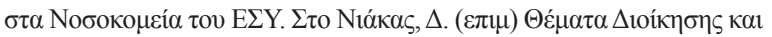

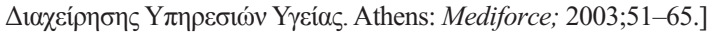

92. Ministry of Health and Social Welfare. Anabathmisi. Athens: MHSS; 2010. Available from: http://www.moh.gov.gr/articles/newspaper/ nomothesia-kanonismoi/194-isxyoysa-nomothesia. Accessed August 23,2012

93. Ministry of Health and Social Welfare. Organosi. Athens: MHSS 2010. Available from: http://www.moh.gov.gr/articles/newspaper/ nomothesia-kanonismoi/194-isxyoysa-nomothesia. Accessed January 23, 2012.

94. Greek Parliament. 3868/2010 Law 'Upgrading the National Health System and Other Provisions of the Ministry of Health and Social

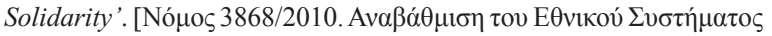

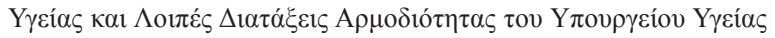

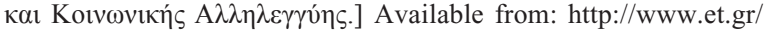
index.php?option=com_wrapper \&view=wrapper \&Itemid=108\&lan $\mathrm{g}=\mathrm{en}$. Accessed January 25, 2012.

95. Rider ME, Makela CJ. A comparative analysis of patients' rights: an international perspective. Intern J Cons St. 2003;27(4):302-315.

96. Involve. Introducing participation. In: People and Participation: How to Put Citizens at the Heart of Decision-making. London: Involve; 2005:5-12. Available from: http://www.involve.org.uk/wp-content/uploads/2011/03/ People-and-Participation.pdf. Accessed January 25, 2012.

97. Kondilis E, Giannakopoulos S, Gavana M, Ierodiakonou I, Waitzkin H, Benos A. Economic crisis, restrictive policies, and the polpulation's health and health care: the Greek case. Am J Public Health. 2013 103(6):973-979.

98. World Health Organisation. Monitoring the impact of the financial crisis on health and health systems in Greece. Copenhagen, WHO; 2015. Available from: www.euro.who.int/en/home/copyright-notice. Accessed August 23, 2015.

99. Ifanti A, Argyriou A, Kalofonou F, Kalofonos H. Financial crisis and austerity measures in Greece: their impact on health promotion policies and public health care. Health Policy. 2013;113(1-2):8-12.

100. World Health Organization. Impact of financial crisis on health: a truly global solution is needed. Copenhagen: WHO; 2009. Available from: www.who.int/mediacentre/news/statements/2009/financial_crisis_20090401/en/. Accessed August 23, 2012.

101. Boudioni M, McLaren S, Lister G. The role of citizenship, culture and voluntary community organisations towards patient empowerment in England and Greece. Int J Caring Sci. 2017;10(1):303-312.

102. Xesfingi S, Vozikis A, Pollalis Y. Citizens' preferences on healthcare expenditure allocation: evidence from Greece. Health Expect. 2015;19:1265-1276. 